\title{
Analyzing of Green Building Concept PT. Dahana to Support Sustainable Development
}

\author{
Febri Saputra ${ }^{1}$, Asmah Sahfitri ${ }^{1}$, Ahmad Subekti Baidowi ${ }^{1}$, Yanif D.K ${ }^{1}$ \\ \{saputrafebri029@gmail.com\} \\ Universitas Pertahanan Indonesia ${ }^{1}$
}

\begin{abstract}
One of reason the increasing energy needs beside population growth is the modernization of civilization. Buildings are called the largest energy consumer, whereas $85 \%$ of Indonesia's energy consumption is still derived from fossil energy. Until 2030 later, Energy savings in building will be priority program in Indonesia. In 2012 by applied the concept of Green Building, PT. Dahana was appointed as the winner of Green Building by Ministry of ESDM. The structure of the buildings and automatic systems in lighting, water and electronic equipment since analyzed by SWOT Method the result shown that the energy efficiency Dahana's building is reached to $10 \%$ in every operation system without reduces or changed the functions, comfort and productivity of staffs in the building. The efficiency of PT. Dahana greatly affect the savings state energy consumption. So the concept of Green Building PT. Dahana can be improved as a reference to similar or new buildings in order to reach Indonesia' sustainable development program.
\end{abstract}

Keywords: Green Building, Efficiency Energy, Sustainable Development

\section{Introduction}

The world is currently faces degradation environmental problem condition such as water, air and land pollution, also the inevitable energy crisis as the development around the world, especially in urban areas [1]

As one of the developing countries that require large energy and rapid population growth with limitations of primary energy productivity that will weaken the carrying capacity in facilitating the needs of the community towards prosperity [2]. Fulfillment of large energy needs precisely acompanied by environmental issues, water resources and energy and health content is increasingly becomes.

The cause of the increase in energy demand in addition to population growth is the modernization of civilization. The building is called the largest energy consumer, while $85 \%$ of Indonesia's energy consumption is still filled from fossil energy. Based on data from the United Nations Environment Program (UN) in 2015, buildings consume 40\% energy, 25\% water, and $40 \%$ of resources in the world. Until 2030, energy saving in the construction sector is a priority aspect of the government [3].

The Government undertakes preventive measures through energy-saving regulations [4]. One of them is Regulation of the Minister of PUPR Number 02 / PRT / M / 2015 on Green Building which requires every building to be built certified energy saving as an effort to reduce the use of energy consumption especially electricity less than $70 \%$ [5]. Several things 
have been done to realize the Green Building predicate, starting from the design stage of the building by the planning team until in the process of construction implementation by PT. Dahana. Planning the construction of the office building by taking into account the aspects of effectiveness and efficiency of water resources and energy, reducing waste, reducing air pollution, able to ensure the existence of environmental health and able to synergize natural and artificial environment. This aspect is based on the planning and design of the building in favor of the principles of sustainable development.

Planning of office building development conducted by PT. Dahana takes into account the aspects of effectiveness and efficiency of water and energy resources, reducing waste, reducing air pollution, being able to ensure environmental health and being able to synergize natural and artificial environments. It refers to the principles of sustainable development programs.

This research is important to study the efforts of energy efficiency and conservation what have been applied in building PT. Dahana. Starting from the layout of the building system lighting, air conditioning and electronic equipment that can create energy efficiency. Although Dahana technology applied to Green Building not including advance. The efficiency can contribute to saving the country's energy consumption up to a few percent despite the many challenges that PT Dahana must face, especially weather changes in the area of Subang is uncertain.

In this research will be limited the scope of the problem as follows:

1. How the application of Green Building concept that PT. Dahana use to efficient the energy use?

2. What aspects that can be developed from the concept of green building PT Dahana?

3. How the strategy can be done to develop the concept of green building PT. Dahana that has been applied?

\section{Methode}

This study uses SWOT analysis by comparing between the external factors of opportunity and threats with internal factor of strength (strength) and weakness. SWOT analysis can be applied by analyzing and sorting things that affect the four factors.

The result of external and internal factor analysis is applied in the SWOT matrix table, where the application is how the strength is able to take advantage and the opportunities, how to overcome the weakness that prevents the advantages of the existing opportunities, then how the power is able to deal with existing threats and the last how to overcome weaknesses that can make it to be real threats or create a new threat.

\subsection{Data Resource}

The primary data are obtained from in-depth interview, observation, and survey while the secondary data are obtained from literature review such as academic text, scientific paper, statistical data, media publications, and law literatures that are related with Green Building Concept to support Sustainable Development.

\subsection{Research Object}

The object of this research is the grouping of factors that influence each SWOT variable, then compiled matrices of comparison to two variables each comparing between S-O, S-T, W- 
$\mathrm{O}$ and W-T to obtain strategies that can be done to improve the concept of Green Building PT. Dahana in order to support the sustainable development program.

\subsection{Data collection technique}

The data collection technique used for this research is the documents study by searching in several sources relevant to this research, interview guide for an in-depth interview, list for survey, and checklist for observation.

\subsection{Data analysis technique}

$\mathrm{T}$ This research uses qualitative method analysis, the authors use data collection techniques with in-depth interview, observation, and survey and conduct literature review. Then the data is processed by SWOT analysis and summed up in the form of qualitative to develop strategies to improve the concept of Green Building PT. Dahana.

\subsection{Research procedure}

This research consists of planning, preparation, implementation, and finishing phases. In the planning and preparation phase, researchers choose the topic that is relevant to the research object. Then, the researchers determine a background, problem formulation, and research goals. Intensification of theories and concepts related to the research topic are also conducted to formulate the thinking framework, hypothesis, and research methods. In the implementation phase, researchers collect secondary data and in the finishing phase, researcher process and analyze data that have been obtained.

\section{Result and Discussion}

\subsection{Green Building Consept PT Dahana}

The concept of green building PT Dahana includes six aspects:

1. Apropriate site development

2. Energy efisiency and Conservation

3. Water Conservation

4. Material Resource and Cycle

5. Indoor Health and Comfort

6. Building Environment Managment

From the six aspects above, the first three aspects are aspects that have the largest roles and portions. Assessment results show that not all aspects have been applied adequately because only water conservation aspect and indoor aspect of health and comfort that get $100 \%$ assessment. Appraisal results of application of green building concept:

1. Apropriate site development : $88,2 \%$

2. Energy efisiency and Conservation : $61,5 \%$

3. Water Conservation : $100 \%$

4. Material Resource and Cycle : $78,6 \%$

5. Indoor Health and Comfort : $100 \%$

6. Building Environment Managment : $84,6 \%$

Implementation of the concept of green building, among others, by using energy-saving technology, the use of natural lighting, the use of materials and environmentally friendly materials, environmental management green. 
Tabel 1. Variabel SWOT

\section{STRENGTH (S)}

- Green building concept and efficient PT. Dahana which has been assessed by the Ministry of Energy and Mineral Resources and has beenreferenced in other buildings.

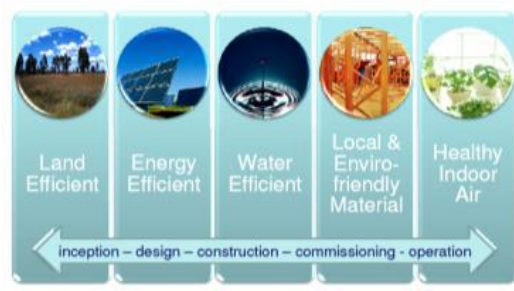

- The greatest savings come from "water conservation" and electricity.

- Dahana became the Runner Up Achievement of Green Building Council Indonesia 2016 2017 category "New Existing Building" and the first champion Energy Efficient Building.

- Electric savings of up to $10 \%$ during extreme weather

- Employees prefer to be in the room during hot weather.

- Lighting and automation systems improve employee performance in terms of practicality.

- opportunities in continuing to develop the efficiency and conservation of buildings.

- Routine maintenance carried out by the building management is evaluated by personnel from Dahana.

- Employee productivity is not reduced due to the concept of Green Building.

- An employee performance appraisal is conducted six months based on targets set each year in the RKAP compared to achievement.

- Dahana has a $100 \%$ target on all aspects of efficiency.

$$
\text { WEAKNESS (W) }
$$
THREAT (T)

- Limited material and equipment.

- The availability of water depends on the flow

\section{OPPORTUNITY (O)}

- All facilities use the concept of green and energy efficiency, but there are buildings that have not been certified.

- Savings on electricity costs.

- Improve employee health because it is located in the forest area and away from the city

- Many new buildings and old buildings that have not implemented the Green Building concept.

- The existence of contest and assessment from the government on the national building energy limits standard.

- Management building is the center of office activities.

- $\quad$ Fast-paced employees do not want anything complicated but still want to save energy.

- Land that is still wide and nature that is still beautiful surrounding Dahana.

- The resulting efficiencies can contribute to saving the country's energy consumption 
of the river.

- Exposure to too much sun at certain hours.

- Investment costs are quite high

- Dahana technology applied to Green Building not including advance.

- Achievement of Dahana on the efficiency aspect has not reached $100 \%$ of Appropriate Site Development (ASD) 88.2\%, Energy Efficiency \& Conservation (EEC) $61.5 \%$, Water Conservation (WC) $100 \%$, Material Resource \& Cycle (MRC) 78.6\%, Indoor Health and Comfort (IHC) 100\%, and Building Environment Management (BEM) $84.6 \%$.
- The uncertain climate also affects the working power of Green Building technology.

- The existence of Building Law Save energy and the construction of new buildings make Dahana no longer a winner.

- Employee performance is also influenced by climate and the long way to PT. Dahana

- Increased energy demand due to increased work activity.

\subsection{Discussion}

SWOT analysis results obtained some criteria of variables that affect the external factors of an opportunity with the threat of internal factors strengths and weaknesses. The results of the analysis of cross matrix of each variable S-O, S-T, W-O and W-T obtained some strategies that can be done to optimize the concept of Green Building PT. Dahana in support of Indonesia's sustainable development which is summarized in the following table.

Tabel 1.2 Matrix analyze of S-O, W-O, S-T, W-T

\begin{tabular}{|c|c|}
\hline S-O & S-T \\
\hline $\begin{array}{l}\text { - For buildings that have been built in } \\
\text { Indonesia such as government buildings. } \\
\text { Theconcept of Green Building PT. Dahana } \\
\text { can be applied by making a study between } \\
\text { the existing condition with the conditions to } \\
\text { be achieved, target targets and ways of } \\
\text { achieving targets and concepts of PT. } \\
\text { Dahana can be a reference and comparison. } \\
\text { - Use more sophisticated technology to } \\
\text { increase savings by more than } 10 \% \text {. } \\
\text { - Evaluation of energy-saving behavior in } \\
\text { employees } \\
\text { Evaluation of energy saving by auditor }\end{array}$ & $\begin{array}{l}\text { - Maintain and enhance the management's } \\
\text { commitment to green concepts, } \\
\text { engineering,and locate good quality local } \\
\text { materials. } \\
\text { - Support and continue to commit to } \\
\text { improving and implementing Green } \\
\text { Building on all buildings } \\
\text { - Create your own energy sources by } \\
\text { exploiting the potential of land and climate } \\
\text { in the form of solar heat to use Solar PV. } \\
\text { The government provides a condition for } \\
\text { the feasibility test of the construction of } \\
\text { buildings with a minimum condition of } \\
10 \% \text {. }\end{array}$ \\
\hline W-O & W-T \\
\hline $\begin{array}{l}\text { - } \begin{array}{l}\text { Provide certification to all energy efficiency } \\
\text { buildings of PT. Dahana for building } \\
\text { operation to be optimal and well } \\
\text { maintained. }\end{array} \\
\text { - Socialization and introduction of the }\end{array}$ & $\begin{array}{l}\text { - Supervise large energy consumption and } \\
\text { technology vulnerable to damage due to } \\
\text { extreme weather } \\
\text { - Synergize SOEs that enable communication } \\
\text { between } \\
\text { - SOEs about the availability of materials, }\end{array}$ \\
\hline
\end{tabular}




\begin{tabular}{lll}
\hline $\begin{array}{l}\text { Dahana Green Building concept to other } \\
\text { buildings. }\end{array}$ & $\begin{array}{l}\text { equipment and resources needed. } \\
\text { Conduct extensive research and }\end{array}$ \\
- $\begin{array}{l}\text { Perform efficiency calculations and apply } \\
\text { energy-saving habits to all employees. }\end{array}$ & $\begin{array}{l}\text { development of Green Building technology, } \\
\text { safety, and testing equipment. }\end{array}$
\end{tabular}

\section{Conclusion}

\subsection{Conclusion}

The concept of green building PT Dahana uses energysaving and automation technologies that support energy-saving behavior. in addition the company also conducts research on energy saving behavior on its employees. Aspek yang dapat dikembangkan dari konsep green building PT Dahana such as :

1) Energy conservation by using natural lighting and energy-saving technologies.

2) Water conservation with optimal water management.

3) Use of environmentally friendly materials.

The strategic can be applied include:

1) Use energy-saving technologies and conduct assessments of employee's energyefficient behavior.

2) Implement green building certification on all buildings and buildings

3) Implementing an energy-efficient behavioral assessment for employees.

4) Conducting an Energy Audit.

\subsection{Recomendation}

The development of green building concept of PT Dahana can be started from the optimization of energy conservation based on the assessment still got a fairly low value compared to other aspects. For a wider scope, the Government may require a minimum energy efficiency aspect of $10 \%$ for government buildings and buildings.

\section{References}

[1] F. Zed, "Green Building \& Gedung Hemat Energi Solusi Krisis Energi Indonesia," J. Unpubl. Malang Univ. Multimed. Nusant., 2016.

[2] K. Kaygusuz, "Energy for sustainable development: A case of developing countries," Renew. Sustain. Energy Rev., vol. 16, no. 2, pp. 1116-1126, 2012.

[3] P. Nejat, F. Jomehzadeh, M. M. Taheri, M. Gohari, and M. Z. A. Majid, "A global review of energy consumption, $\mathrm{CO} 2$ emissions and policy in the residential sector (with an overview of the top ten CO2 emitting countries)," Renew. Sustain. energy Rev., vol. 43, pp. 843-862, 2015.

[4] A. Hakim, Bangunan Hijau, Tantangan Pembangunan Berkelanjutan di Surabaya. Jatim: Antara News, 2018.

[5] USAID, Panduan Penghematan Energi di Gedung Pemerintah Sesuai Amanat Peraturan Menteri ESDM no. 13 tahun 2012 tentang Penghematan Pemakaian Listrik. Jakarta: ICED Project, 2014. 